\title{
Synovial Sarcoma Microvesicles Harbor the SYT-SSX Fusion Gene Transcript: Comparison of Different Methods of Detection and Implications in Biomarker Research
}

\author{
A. Fricke, ${ }^{1}$ P. V. Ullrich, ${ }^{1}$ A. F. V. Cimniak, ${ }^{1}$ M. Follo, ${ }^{2}$ S. Nestel, ${ }^{3}$ B. Heimrich, ${ }^{3}$ \\ I. Nazarenko, ${ }^{4}$ G. B. Stark, ${ }^{1}$ H. Bannasch, ${ }^{1}$ D. Braig, ${ }^{1}$ and S. U. Eisenhardt ${ }^{1}$ \\ ${ }^{1}$ Clinic for Plastic and Hand Surgery, Medical Center - Faculty of Medicine, University of Freiburg, Freiburg, Germany \\ ${ }^{2}$ Clinic for Hematology, Oncology and Stem Cell Transplantation, Medical Center - Faculty of Medicine, \\ University of Freiburg, Freiburg, Germany \\ ${ }^{3}$ Institute of Anatomy and Cell Biology, University of Freiburg, Freiburg, Germany \\ ${ }^{4}$ Institute for Environmental Health Sciences and Hospital Infection Control, Medical Center - Faculty of Medicine, \\ University of Freiburg, Freiburg, Germany
}

Correspondence should be addressed to A. Fricke; alba.fricke@uniklinik-freiburg.de

Received 5 November 2015; Revised 31 January 2016; Accepted 15 February 2016

Academic Editor: Yanfang Chen

Copyright (C) 2016 A. Fricke et al. This is an open access article distributed under the Creative Commons Attribution License, which permits unrestricted use, distribution, and reproduction in any medium, provided the original work is properly cited.

Background. Synovial sarcoma is an aggressive soft-tissue malignancy. This study examines the presence of the SYT-SSX fusion transcript in synovial sarcoma microvesicles as well as its potential role as a biomarker for synovial sarcoma. Patients and Methods. Microvesicle release of synovial sarcoma cells was examined by transmission electron microscopy. RNA-content was analyzed by qPCR, nested PCR, nested qPCR, and droplet digital PCR to compare their sensitivity for detection of the SYT-SSX fusion gene transcript. Whole blood RNA, RNA of mononuclear cells, and microvesicle RNA of synovial sarcoma patients were analyzed for the presence of the fusion gene transcripts. Results. Electron microscopic analysis revealed synovial sarcoma cells releasing membraneenclosed microvesicles. In vitro, the SYT-SSX fusion gene transcript was detected in both synovial sarcoma cells and microvesicles. Nested qPCR proved to be the most sensitive in detecting the SYT-SSX fusion gene mRNA. In contrast, the fusion gene transcript was not detected in peripheral blood cells and microvesicles of synovial sarcoma patients. Conclusion. Synovial sarcoma cells release microvesicles harboring the SYT-SSX fusion transcript. Nested qPCR proved to be the most sensitive in detecting the SYT-SSX fusion gene mRNA; however, more sensitive assays are needed to detect cancer-specific microvesicles in the peripheral blood of cancer patients.

\section{Introduction}

Synovial sarcoma is an aggressive soft-tissue malignancy and constitutes one of the largest subgroups of soft-tissue sarcoma, especially in adolescents and young adults $[1,2]$. The cytogenetically defined translocation $\mathrm{t}(\mathrm{X} ; 18)(\mathrm{p} 11.2 ; \mathrm{q} 11.2)$ found in human synovial sarcoma results in the fusion of the SYT gene on chromosome 18 to SSX1, SSX2, or SSX4 on chromosome X at Xp11.2, leading to the formation of SYTSSX fusion transcript [3-5]. This fusion transcript competes for assembly with wild-type SS18, forming an altered complex lacking the tumor suppressor BAF47 (hSNF5), resulting in Sox 2 activation and leading to proliferation of synovial sarcoma tumor cells [6]. Also, SYT-SSX has been shown to affect polycomb-mediated gene repression and SWI/SNF chromatin remodeling as well as deregulating WNT- $\beta$ catenin signaling in synovial sarcoma [7]. Interestingly, while expression of the SYT-SSX2 oncoprotein leads to induction of synovial sarcoma with $100 \%$ penetrance in immature myoblasts, its expression in more differentiated cells induces myopathy without tumor induction in a mouse model [8].

The presence of the SYT-SSX fusion transcript enables specific and sensitive molecular diagnosis of synovial sarcoma, being detectable in almost all synovial sarcoma tissues 
$[9,10]$. As shown in a recent meta-analysis of 10 studies comprising 902 patients with synovial sarcoma, there are no significant differences in overall survival and diseasespecific survival rates between patients with synovial sarcoma expressing the SYT-SSX1 and SYT-SSX2 fusion gene; however, SYT-SSX1 seems to represent an unfavorable prognostic factor of progression- and metastasis-free survival [11]. Nevertheless, the prognostic value of the fusion gene variant for survival still remains a matter of debate $[10,12]$.

Since it has been shown that tumor cells release small vesicles containing cell-specific proteins, surface markers, and even mRNA variants specific for certain neoplasms such as the EGFRvIII splice variant in glioblastoma [13], the aim of this study is to evaluate whether microvesicles shed by synovial sarcoma cells carry the tumor-specific fusion gene SYT-SSX transcripts. Moreover, this study analyzes the sensitivity of different methods for the detection of the SYT-SSX fusion genes as a potential biomarker for synovial sarcoma.

\section{Materials and Methods}

2.1. Cell Culture. Human synovial sarcoma cells (cell line $1273 / 99$, kindly provided by Dr. Marcus Renner, Institute of Pathology, University of Heidelberg), which harbor the SYT-SSX2 fusion gene [14], were cultured in F-12 nutrient mixture (Ham) (Life Technologies, Carlsbad, CA, USA) supplemented with $10 \%$ FBS superior and $100 \mathrm{U} / \mathrm{mL}$ PenicillinStreptomycin. THP-1 cells (human acute monocytic leukemia cell line) were cultured in RPMI medium 1640 (with LGlutamine; Life Technologies) supplemented with 10\% FBS superior and $100 \mathrm{U} / \mathrm{mL}$ Penicillin-Streptomycin.

2.2. Microvesicle-Purification of Synovial Sarcoma Cells. Since fetal bovine serum was described to contain extracellular vesicles which might alter the results of the analysis of tumor microvesicles [15], synovial sarcoma cells were cultured in microvesicle-free medium (DMEM containing $5 \%$ microvesicle-depleted fetal bovine serum/dFBS) until $80 \%$ confluency, prepared by ultracentrifugation at $110,000 \mathrm{~g}$ for $16 \mathrm{~h}$ to remove bovine microvesicles as described by Skog et al. [13] and conditioned medium was collected after $48 \mathrm{~h}$. Microvesicles were purified from the conditioned supernatant by differential centrifugation steps as previously described [16]. Briefly, conditioned medium was centrifuged for $10 \mathrm{~min}$ at $300 \mathrm{~g}$ to eliminate cell contamination. Supernatants were further centrifuged for $20 \mathrm{~min}$ at $16,500 \mathrm{~g}$. Microvesicles were then sterile-filtered $(0.22 \mu \mathrm{m})$ and pelleted by ultracentrifugation at $110,000 \mathrm{~g}$ for $80 \mathrm{~min}$. The microvesicle pellets were then washed in PBS, pelleted again at $110,000 \mathrm{~g}$ for $80 \mathrm{~min}$, dissolved in PBS, and stored at $-80^{\circ} \mathrm{C}$ until further use.

2.3. Transmission Electron Microscopy (TEM). Synovial sarcoma cells were plated on glass slides in 24 -well plates. At $80 \%$ confluency, the medium was removed and cells were rinsed and incubated in PBS at $37^{\circ} \mathrm{C}$ for $90 \mathrm{~min}$ in order to trigger microvesicle release. Cells were subsequently washed with PBS and fixed with $0.1 \mathrm{M}$ phosphate buffer (PB) containing
$4 \%$ paraformaldehyde (PFA) and $2 \%$ glutaraldehyde (GA) for $30 \mathrm{~min}$. The cells were then rinsed in $\mathrm{ddH}_{2} \mathrm{O}$ and $0.1 \mathrm{M}$ $\mathrm{PB}$ for each $10 \mathrm{~min}$ and osmicated $\left(1 \% \mathrm{OsO}_{4}\right.$ and $6.86 \%$ sucrose in $0.1 \mathrm{~PB}$ ) for $40 \mathrm{~min}$. Thereafter, the cells were rinsed several times in $0.1 \mathrm{M} \mathrm{PB}$, immersed in $50 \%$ ethanol $(\mathrm{EtOH})$ for $10 \mathrm{~min}$, incubated in 1\% uranyl acetate in $70 \% \mathrm{EtOH}$ for $35 \mathrm{~min}$, and dehydrated in a graded series of ethanol (90\%, 95\%, and 100\%). After rinsing twice in propylene oxide for $10 \mathrm{~min}$, the glass coverslips with the cells attached on top were immersed in a 1:1 mixture of propylene oxide and Durcopan (Fluka, Buchs, Switzerland) for $1 \mathrm{~h}$. This was followed by embedding the cells in Durcopan overnight; then, they were mounted under coverslips with fresh Durcopan and left to incubate for $24 \mathrm{~h}$ at $56^{\circ} \mathrm{C}$ for polymerization. Ultrathin sections $(40 \mathrm{~nm})$ were cut, collected on Formvarcoated nickel grids, and digitally photographed (LEO $906 \mathrm{E}$, Zeiss, Oberkochen, Germany) using SIS software (Olympus, Hamburg, Germany). The method was previously described by Hellwig et al. [17] and adapted with slight alterations.

In order to provide characterization evidence of the microvesicles released from the synovial sarcoma cells, microvesicles purified using the differential centrifugation steps described above were further analyzed by TEM. Briefly, after $5 \mathrm{~min}$ of adsorption, fixation of the microvesicle pellets was carried out for $5 \mathrm{~min}$ by the use of $1 \%$ glutaraldehyde (GA). The microvesicle pellets were then rinsed four times in $\mathrm{ddH}_{2} \mathrm{O}$ and negative staining was carried out for $1 \mathrm{~min}$ using $1 \%$ uranyl acetate. Negative staining is a method in which contrast is not applied to the object but to its environment, with the result resembling an inverted traditional TEM image [18]. Microvesicles were then digitally photographed as described above.

2.4. Nanoparticle Tracking Analysis (NTA). NTA was carried out using the ZetaView ${ }^{\circledR}$ PMX 110 Nanoparticle Tracking Analyzer (Particle Metrix, Meerbusch, Germany) and the corresponding ZetaView ${ }^{\circledR}$ software. Camera shutter speed was maintained at $130 \mathrm{~ms}$. Samples were diluted in sterilefiltered PBS to concentrations of 1:500 for purified synovial sarcoma microvesicles and 1:1000-1:2500 for purified serum microvesicles of patients with synovial sarcoma. Videos were recorded at 11 positions and 5 cycles with camera sensitivity ranging from $65 \%$ to $81 \%$. Temperature was monitored manually and ranged from 21.0 to $22.0^{\circ} \mathrm{C}$.

2.5. RNase A Treatment. To evaluate whether the fusion gene transcript was present inside the microvesicles, the pellet was dissolved in PBS and incubated for $30 \mathrm{~min}$ at $37^{\circ} \mathrm{C}$ with RNase A (Thermo Fisher Scientific, Waltham, MA, USA) at a final concentration of $100 \mu \mathrm{g} / \mathrm{mL}$ or PBS as a negative control before RNA extraction as previously described by Skog et al.

2.6. Study Population. All patients included in this study received treatment from specialists in the interdisciplinary tumor board of the Comprehensive Cancer Center Freiburg (CCCF). Detection of the SYT-SSX fusion transcripts by chromogenic in situ hybridization (CISH), fluorescence in situ hybridization (FISH), or qPCR confirmed diagnosis of synovial sarcoma. Of the patients with active synovial 
sarcoma included in the study population, seven presented with metastasized disease, while one presented with localized disease of the lower extremity. Two of the patients received chemotherapy and one patient received radiotherapy within the last six weeks before blood withdrawal (Table 3). The control group consisted of healthy adults matched to the synovial sarcoma group in terms of age, sex, and body mass index (BMI) (Table 4).

2.7. Ethics, Consent, and Permissions. Signed informed consent was obtained from all participants, allowing analysis of blood samples, tumor tissue, and all clinical data. The Ethics Committee of the Albert-Ludwigs-University of Freiburg, Germany, approved the study. The design and performance of the study are in accordance with the Declaration of Helsinki.

2.8. Blood Sampling. All blood samples were collected by puncture of the antecubital vein without tourniquet through a 20 -gauge needle. The first $3 \mathrm{~mL}$ of blood were discarded.

2.9. Whole Blood RNA. Each $2.5 \mathrm{~mL}$ of whole blood was collected and stabilized in PAXgene Blood RNA Tubes (PreAnalytiX, Hombrechtikon, Switzerland) as previously described by Keller et al. [19]. The RNA Tubes were incubated for at least 2 hours at room temperature (RT) after blood collection to ensure complete lysis of blood cells and were then stored at $-20^{\circ} \mathrm{C}$ until further processing. Before starting the procedure, they were equilibrated to room temperature. Total RNA $>18$ nucleotides (including miRNA) was purified manually using the PAXgene Blood miRNA Kit (PreAnalytiX) according to the manufacturer's protocol.

2.10. Separation of Mononuclear Cell Fraction. Approximately $9 \mathrm{~mL}$ of heparinized peripheral blood of patients with active synovial sarcoma was drawn and diluted with half the amount of PBS, then being gently overlaid on $4 \mathrm{~mL}$ Biocoll Separating Solution (Biochrom AG, Berlin, Germany) and centrifuged at $1200 \mathrm{~g}$ for $15 \mathrm{~min}$ at RT. The layer containing mononuclear cells was isolated from the interface, diluted with $10 \mathrm{~mL}$ PBS, and centrifuged at $300 \mathrm{~g}$ for $5 \mathrm{~min}$. The supernatant was discarded and the pellet was dissolved in $4.5 \mathrm{~mL}$ FBS (fetal bovine serum superior; Biochrom AG), supplemented with $10 \%$ dimethyl sulfoxide (Sigma-Aldrich, St. Louis, MO, USA), then being stored at -80 degrees Celsius until further use.

2.11. Microvesicle-Purification of Serum Samples. $7 \mathrm{~mL}$ of serum samples from healthy controls and synovial sarcoma patients was centrifuged at $2500 \mathrm{~g}$ for $15 \mathrm{~min}$ at RT. The supernatant was then further centrifuged at $2500 \mathrm{~g}$ for $15 \mathrm{~min}$ at RT. Microvesicles were subsequently pelleted by ultracentrifugation at $110,000 \mathrm{~g}$ for $80 \mathrm{~min}$ as described previously by Skog et al. [13] and washed once in PBS. The pellet was resolved in $15 \mu \mathrm{L}$ PBS before proceeding to RNA extraction.

2.12. RNA Isolation. Total RNA of both cells and microvesicles was purified using the RNeasy Mini Kit (Qiagen, Hilden, Germany) according to the manufacturer's protocol. RNA was quantified using the Nanodrop 2000 (Thermo Fisher Scientific).
2.13. Capillary Electrophoresis. RNA quality and quantity of cells and microvesicles were assessed by capillary electrophoresis using the Fragment Analyzer (Advanced Analytical Technologies GmbH, Heidelberg, Germany) and standard/high sensitivity RNA Analysis kits.

2.14. DNase-I Digestion and Conversion to cDNA. RNA was isolated and DNAse digestion and conversion to cDNA were carried out by the DNAse-I, amplification grade set (Life Technologies), and the AffinityScript Multi Temperature cDNA Synthesis Kit (Agilent Technologies, Santa Clara, CA, USA) according to the manufacturer's protocol. The reverse transcription reaction was incubated for $10 \mathrm{~min}$ at $25^{\circ} \mathrm{C}$, followed by $1 \mathrm{~h}$ at $42^{\circ} \mathrm{C}$ and $15 \mathrm{~min}$ at $70^{\circ} \mathrm{C}$.

2.15. $q P C R$. For detection of the SYT-SSX1 and SYT-SSX2 fusion gene, qPCR was performed using the Absolute qPCR ROX Mix (Thermo Fisher Scientific) and the following primers: SS18-SSX1 + FAM (Hs 03024820_ft), SS18-SSX2 + FAM (Hs03024398_ft) (TaqMan Gene Expression Assays; Life Technologies), and the GAPDH-Primer Set (GAPDH-probe 899, GAPDH-875F, and GAPDH 946-R; Eurofins MWG Operon, Huntsville, AL, USA) as the internal control. Briefly, the cycling conditions were enzyme activation at $95^{\circ} \mathrm{C}$ for $15 \mathrm{~min}$, followed by 50 cycles of denaturation at $95^{\circ} \mathrm{C}$ for $15 \mathrm{~s}$ and annealing/extension at $60^{\circ} \mathrm{C}$ for $1 \mathrm{~min}$. Ct-values $<39$ were considered as positive.

2.16. Nested PCR. Nested PCR was carried out using the Taq PCR Core Kit (Qiagen) according to the manufacturer's protocol. The following PCR primers were used for the first-round PCR: 5-CAACAGCAAGATGCATACCA-3 and 5-CACTTGCTATGCACCTGATG-3. The primers of the second-round PCR were designed to amplify both SYT-SSX1 and SYT-SSX2 subtypes: 5-ACAGCCTGGACCACCACAGC-3 and 5-AGGCATGTTTCCCCCTTTTG-3, yielding PCR products of 212 base pairs (bp). The primer sequences were adapted from Hashimoto et al. [20]. Cycling conditions were 35 cycles of denaturation at $94^{\circ} \mathrm{C}$ for $40 \mathrm{~s}$, annealing at $50^{\circ} \mathrm{C}$ for $1 \mathrm{~min}$, and extension at $72^{\circ} \mathrm{C}$ for $1 \mathrm{~min}$ after an initial denaturation step of $94^{\circ} \mathrm{C}$ for $3 \mathrm{~min}$. Afterwards, a final extension step was carried out at $72^{\circ} \mathrm{C}$ for $10 \mathrm{~min}$.

2.17. Nested qPCR. qPCR was performed of the secondround PCR product of the nested PCR from whole blood, microvesicle, and the mononuclear cell fraction of synovial sarcoma and healthy donors using the SS18-SSX1 + FAM (Hs 03024820_ft) and SS18-SSX2 + FAM (Hs03024398_ft) primers.

2.18. Droplet Digital PCR (ddPCR). Droplet digital PCR was carried out using the SS18-SSX1 + FAM (Hs 03024820_ft) and SS18-SSX2 + FAM (Hs03024398_ft) primers and the QX100 ddPCR system (Bio-Rad, Hercules, CA, USA) according to the manufacturer's protocol. Hereby, PCR amplification is carried out within each droplet using a thermal cycler after partitioning of samples into droplets by the QX100 droplet generator. After PCR, droplets are streamed in a single file on a QX100 droplet reader, which counts the fluorescent positive 


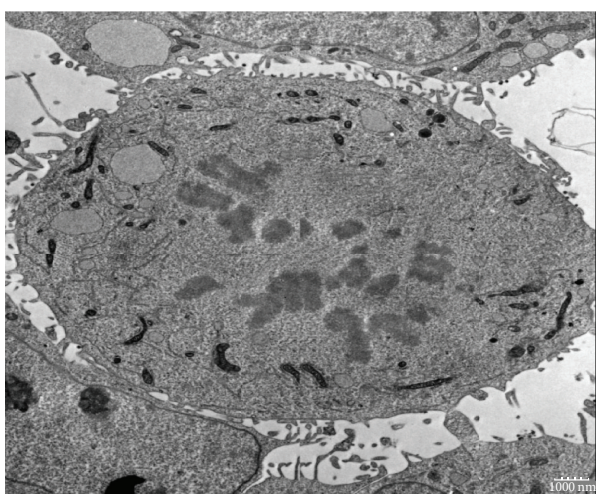

(a)

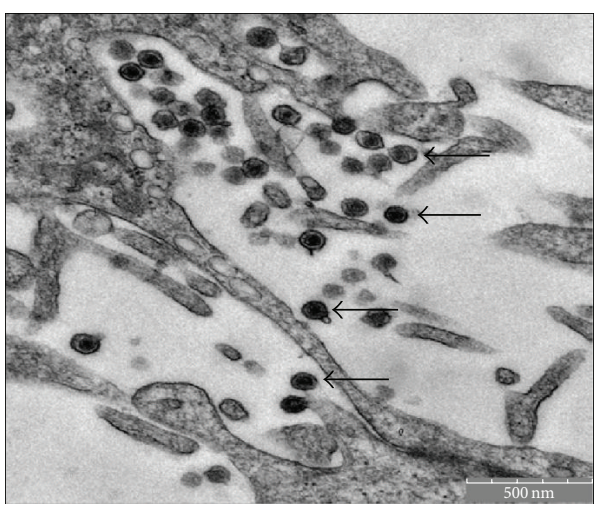

(c)

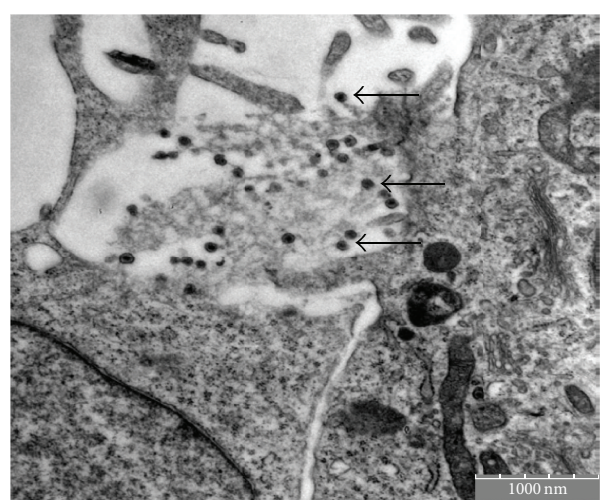

(b)

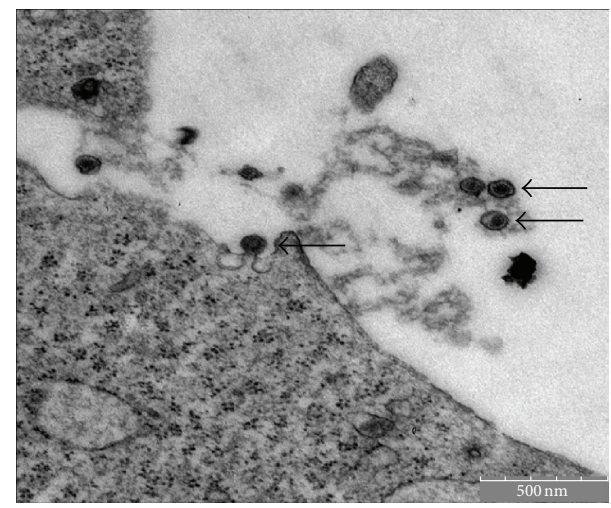

(d)

FIGURE 1: Visualization of synovial sarcoma cells and microvesicles by transmission electron microscopy (TEM). (a) Synovial sarcoma cell. Bar indicating $1000 \mathrm{~nm}$. ((b)-(d)) Close-up view which shows the release of microvesicles (arrows) by the synovial sarcoma cell. Bars indicating $1000 \mathrm{~nm}(\mathrm{~b})$ and $500 \mathrm{~nm}((\mathrm{c})$ and (d)).

and negative droplets to calculate target RNA concentration. Event counts $<5$ were interpreted as not detected, since negative controls showed up to five events.

2.19. Statistics. $p$ values below 0.05 were considered statistically significant. Statistical analysis was carried out using Student's $t$-test for independent samples.

Data were presented as mean value \pm standard error of mean (SEM). All data were analyzed with GraphPad Prism 6.0 (GraphPad Software, San Diego, CA, USA).

\section{Results and Discussion}

Electron microscopy showed synovial sarcoma cells releasing microvesicles enclosed by a protective membrane (Figures 1(a)-1(d)). Synovial sarcoma microvesicles purified by differential centrifugation steps were further analyzed by electron microscopy (Figure 2) and were shown to correspond to the microvesicles released from synovial sarcoma cells as depicted in Figures 1(a)-1(d) in size and aspect.

To further characterize the microvesicles, Nanoparticle Tracking Analysis (NTA) was carried out. Microvesicles purified from serum of patients with active synovial sarcoma showed similar mean diameter peaks when compared to microvesicles purified from synovial sarcoma cells $(151.7 \mathrm{~nm}$ (Figures 3(a)-3(c)) and $154.4 \mathrm{~nm}$ (Figures 3(d)-3(f)), resp.). Mean concentration levels of microvesicles in serum of patients with active synovial sarcoma and synovial sarcoma cell supernatant were $3155.0 \times 10^{9}$ particles $/ \mathrm{mL}$ (Figures $3(\mathrm{a})-3(\mathrm{c}))$ and $18.60 \times 10^{9}$ particles/mL (Figures 3(d)-3(f)), respectively.

Performing bioanalysis of RNA from synovial sarcoma microvesicles and their cells of origin, significant differences in RNA size distribution were found, with microvesicle RNA lacking the characteristic ribosomal RNA peaks of cellular RNA (Figure 4).

In vitro, the SYT-SSX2 fusion gene transcript was detected in both synovial sarcoma cells and microvesicles $(n=3)$ (Figure 5(a)), with microvesicle RNase A treatment showing only a small decrease of the fusion gene mRNA compared to untreated microvesicles $(n=3)$ (Figure 5(b)), thus showing that the mRNA is contained inside the microvesicles, being protected from the RNase by the lipid bilayer.

When comparing the sensitivity of nested qPCR, qPCR, nested PCR, and droplet digital PCR for detection of the SYTSSX2 fusion gene transcript in synovial sarcoma cells and microvesicles, nested qPCR and qPCR showed the highest 


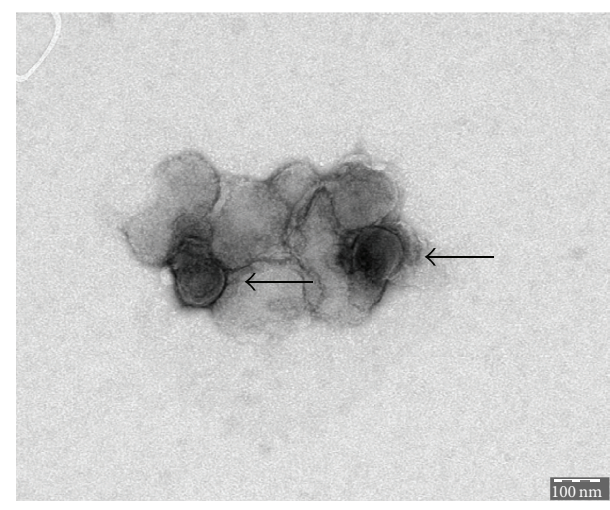

(a)

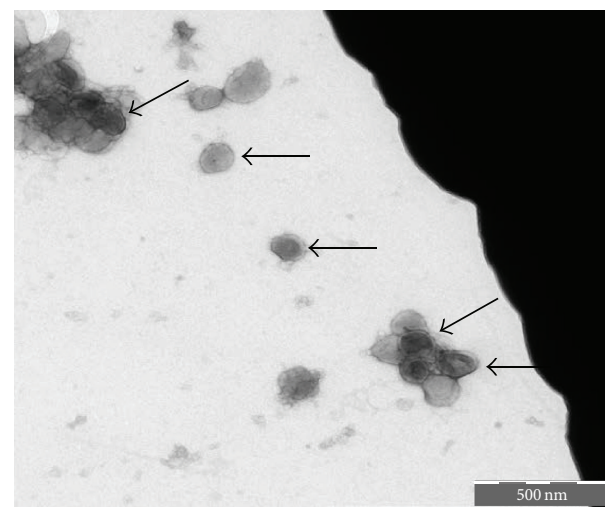

(c)

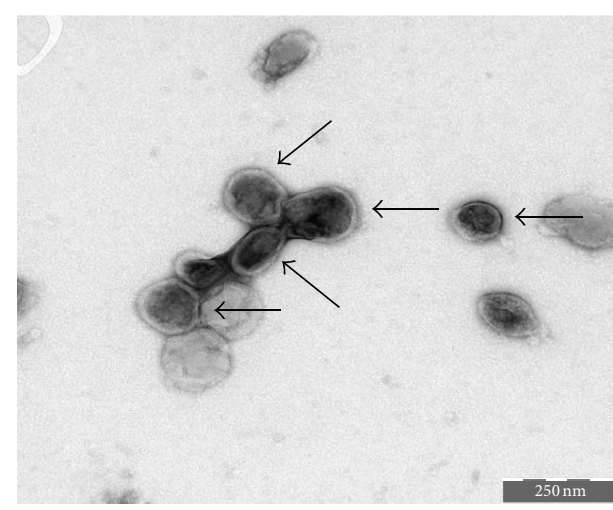

(b)

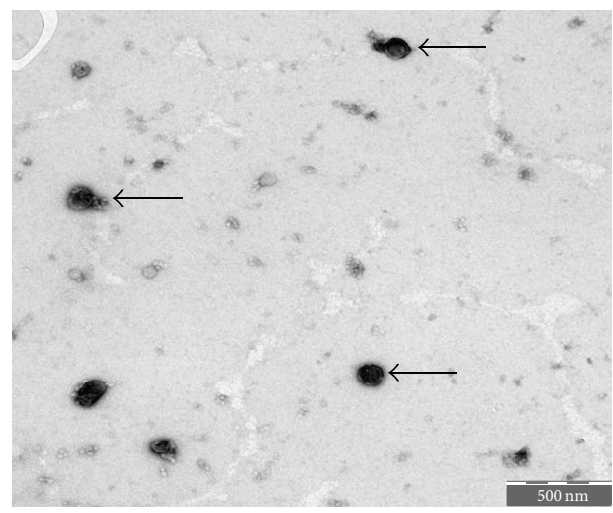

(d)

FIGURE 2: Visualization of purified synovial sarcoma microvesicles (arrows) by transmission electron microscopy (TEM). (a) Bar indicating $100 \mathrm{~nm}$. (b) Bar indicating $250 \mathrm{~nm}$. ((c) and (d)) Bar indicating $500 \mathrm{~nm}$.

sensitivity for the detection of the fusion gene transcript in both microvesicles and cells, whereas ddPCR showed the lowest sensitivity (Tables 1 and 2).

We then employed different assays for detection of the SYT-SSX fusion transcripts to peripheral blood samples of patients with synovial sarcomas. Analysis of corresponding tumor tissue revealed that two patients presented the SYTSSX2 fusion gene phenotype, while five presented the SYTSSX1 phenotype [21], which has been described as more common [10, 22]. Tumor tissue of one patient was not available for analysis. Information regarding disease and therapy status of sarcoma patients is illustrated in Table 3. Synovial sarcoma patients $(n=8)$ did not differ significantly from healthy controls $(n=5)$ concerning age, BMI, hemoglobin $(\mathrm{Hb})$ level, platelet count, and leukocyte count (Table 4).

Nested qPCR (Figure 6(a)), qPCR (Figure 6(b)), nested PCR (Figure 7), and ddPCR (Figure 8) did not detect the SYT-SSX1/2 fusion gene transcripts in the extracted whole blood, mononuclear cells, and microvesicles of synovial sarcoma patients and healthy donors.

Thus, we could show that synovial sarcoma cells release small vesicles harboring the synovial sarcoma cell-specific fusion gene transcript SYT-SSX. Hereby, the size distribution of RNA contained in these microvesicles differs significantly
TABLE 1: Comparison of sensitivity of nested PCR, qPCR, nested PCR, and ddPCR in the detection of the SYT-SSX2 fusion gene in synovial sarcoma cells. D: detected, ND: not detected.

\begin{tabular}{lcccc}
\hline $\begin{array}{l}\text { Amount of total } \\
\text { RNA in ng } \\
\text { (synovial } \\
\text { sarcoma cells) }\end{array}$ & Nested qPCR & qPCR & Nested PCR & ddPCR \\
\hline 25,000 & D & D & D & D \\
12,500 & D & D & D & D \\
6,250 & D & D & D & ND \\
3,125 & D & D & D & ND \\
1,562 & D & D & ND & ND \\
0,781 & D & D & ND & ND \\
0,391 & D & ND & ND & ND \\
0,195 & D & ND & ND & ND \\
0,098 & ND & ND & ND & ND \\
0,049 & ND & ND & ND & ND \\
0,024 & ND & ND & ND & ND \\
0,012 & ND & ND & ND & ND \\
0,006 & ND & ND & ND & ND \\
0,003 & ND & ND & ND & ND \\
\hline
\end{tabular}




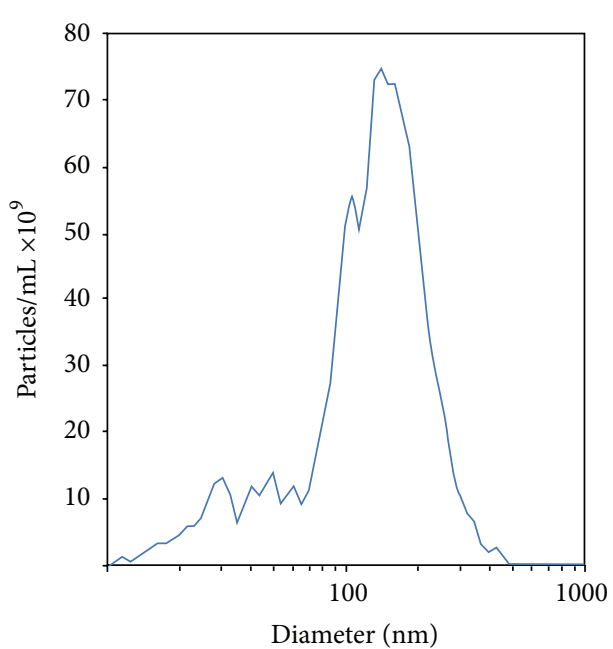

(a)

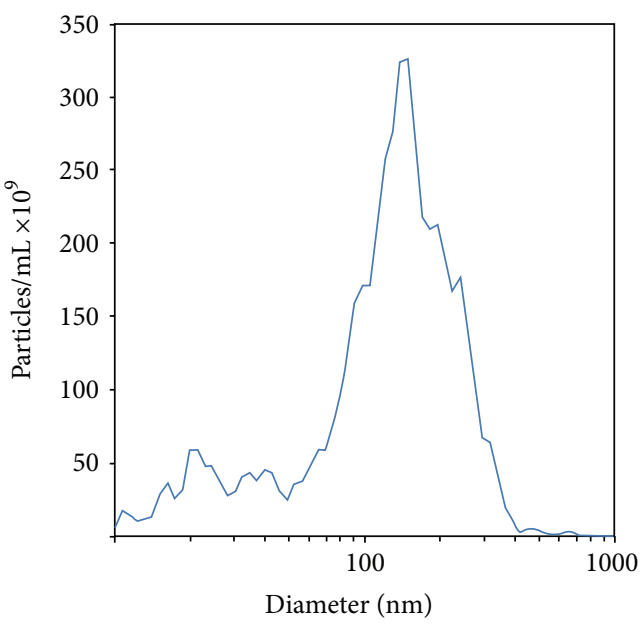

(c)

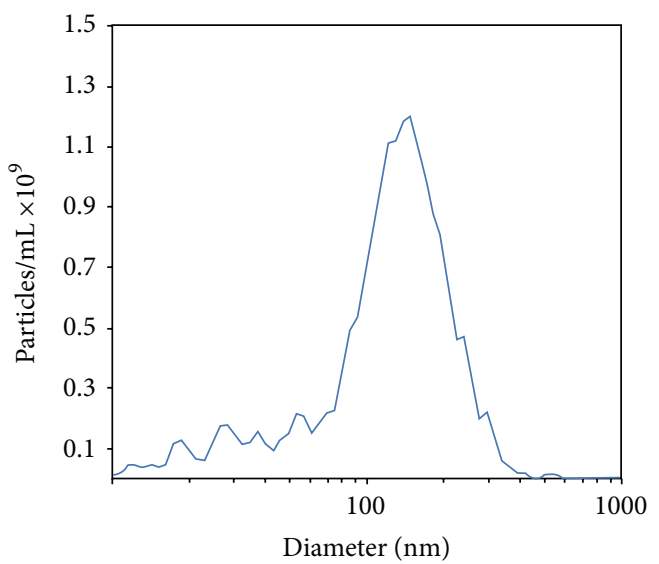

(e)

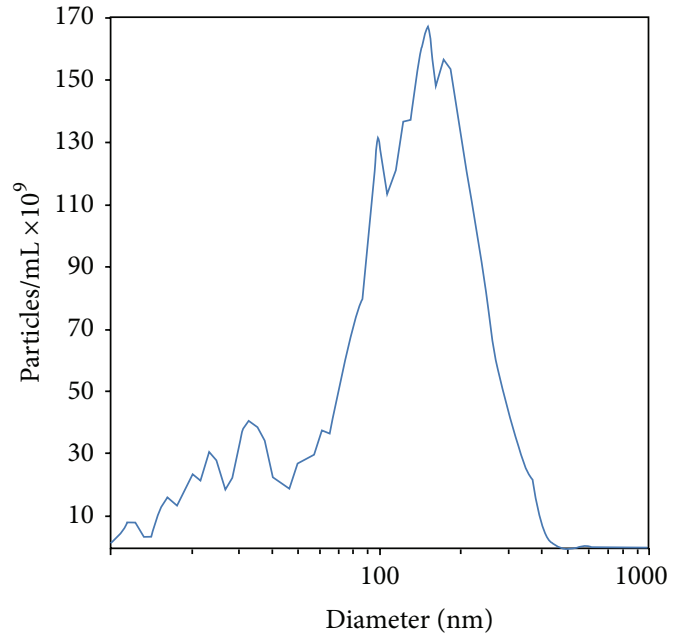

(b)

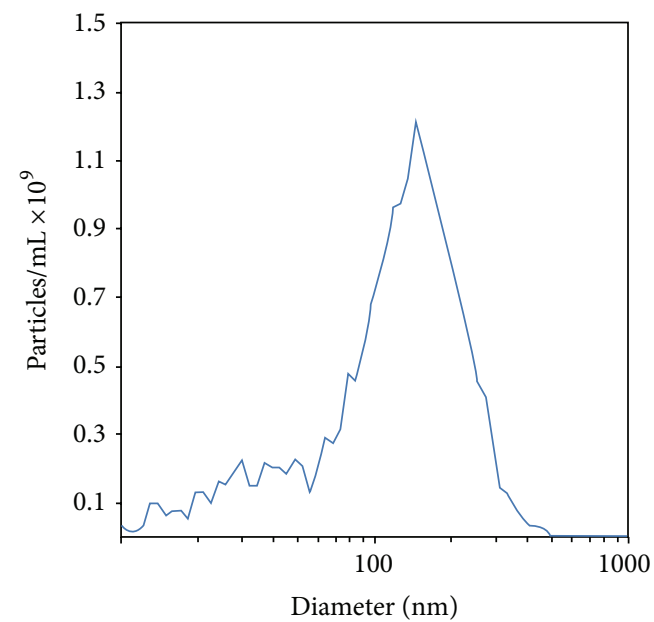

(d)

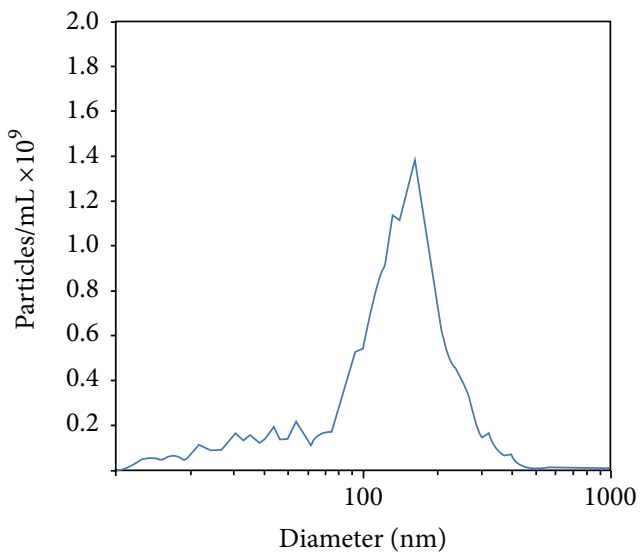

(f)

FIGURE 3: Nanoparticle Tracking Analysis (NTA) of microvesicles purified from serum of patients with active synovial sarcoma ((a)-(c)) and synovial sarcoma cells ((d)-(f)). Mean diameter peaks were $151.7 \mathrm{~nm}$ for microvesicles extracted from synovial sarcoma patient serum ((a)(c)) and $154.4 \mathrm{~nm}((\mathrm{~d})-(\mathrm{f}))$ for microvesicles purified from synovial sarcoma cells. Mean concentration levels were $3155.0 \times 10^{9} \mathrm{particles} / \mathrm{mL}$ in serum of patients with active synovial sarcoma $((\mathrm{a})-(\mathrm{c}))$ and $18.60 \times 10^{9}$ particles $/ \mathrm{mL}$ in synovial sarcoma cell supernatant $((\mathrm{d})-(\mathrm{f}))$. 


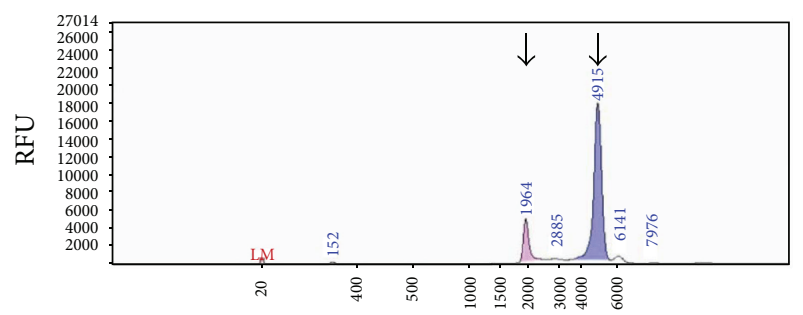

(a)

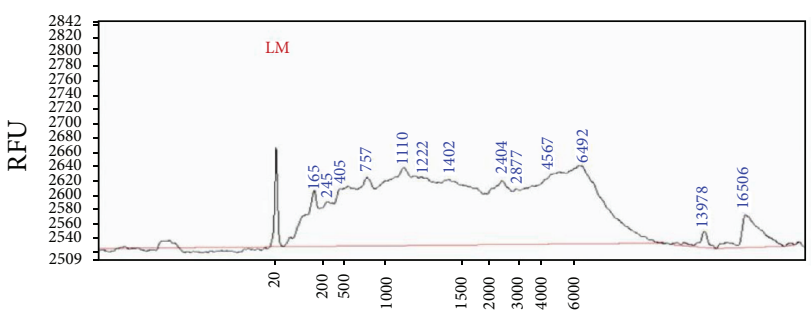

(b)

FIGURE 4: Differences in RNA size distribution (a) RNA of 1273/99 synovial sarcoma cells showing the characteristic ribosomal peaks of cellular RNA. The two prominent peaks (arrows) represent 18S (left) and 28S (right) ribosomal RNA. (b) RNA of microvesicles lack the characteristic ribosomal 18 S and 28 S peaks.

TABLE 2: Comparison of sensitivity of nested PCR, qPCR, nested PCR, and ddPCR at detection of SYT-SSX fusion gene in 1273/99 synovial sarcoma microvesicles. D: detected, ND: not detected.

\begin{tabular}{|c|c|c|c|c|}
\hline $\begin{array}{l}\text { Amount of total } \\
\text { RNA in ng } \\
\text { (synovial } \\
\text { sarcoma } \\
\text { microvesicles) }\end{array}$ & Nested qPCR & $\mathrm{qPCR}$ & Nested PCR & ddPCR \\
\hline 25,000 & $\mathrm{D}$ & $\mathrm{D}$ & $\mathrm{D}$ & $\mathrm{D}$ \\
\hline 12,500 & $\mathrm{D}$ & $\mathrm{D}$ & $\mathrm{D}$ & $\mathrm{D}$ \\
\hline 6,250 & $\mathrm{D}$ & $\mathrm{D}$ & $\mathrm{D}$ & $\mathrm{D}$ \\
\hline 3,125 & $\mathrm{D}$ & $\mathrm{D}$ & $\mathrm{D}$ & ND \\
\hline 1,562 & $\mathrm{D}$ & $\mathrm{D}$ & ND & ND \\
\hline 0,781 & $\mathrm{D}$ & $\mathrm{D}$ & ND & ND \\
\hline 0,391 & $\mathrm{D}$ & $\mathrm{ND}$ & $\mathrm{ND}$ & ND \\
\hline 0,195 & $\mathrm{D}$ & ND & ND & ND \\
\hline 0,098 & $\mathrm{D}$ & ND & ND & ND \\
\hline 0,049 & $\mathrm{D}$ & ND & ND & ND \\
\hline 0,024 & $\mathrm{D}$ & ND & ND & ND \\
\hline 0,012 & $\mathrm{D}$ & ND & ND & ND \\
\hline 0,006 & $\mathrm{D}$ & ND & ND & ND \\
\hline 0,003 & ND & ND & $\mathrm{ND}$ & ND \\
\hline
\end{tabular}

to their cells of origin. As shown by its resistance to RNase treatment, the fusion gene transcript seems to be located inside the protective microvesicle membrane. To our knowledge, this is the first study to show that the SYT-SSX fusion transcript is present not only in synovial sarcoma cells, but also in synovial sarcoma microvesicles.

Since it has been shown that tumor microvesicles act as intercellular messengers, activate signaling pathways, and modulate cell survival when being engulfed by other cells such as monocytes [23], synovial sarcoma microvesicles might serve as important tumor mediators, which interact with immune cells in the tumor's periphery and throughout the circulation as well as with nearby host tissues. In this context, Andreola et al. showed that tumor cells release Fas ligand-bearing microvesicles, which trigger Fas-dependent apoptosis of lymphoid cells, thus impairing the efficacy of antitumor immune responses, a mechanism known as "Fas tumor counterattack" [24]. This finding suggests that one of the major roles of the detected tumor microvesicles might be the role of "guardsmen" interfering with lymphocytes and other immune cells and impeding them from applying their antitumor activity. As it could be proven that tumor cells with highly metastatic potential release a greater amount of tumor microvesicles than cells with low metastatic ability [25], microvesicles seem the ideal biomarkers for the detection of tumor activity. This could further be underlined by the fact that the detection of the synovial sarcoma-specific fusion gene in microvesicles can be detected in much lower total RNA concentrations than in their cells of origin (Tables 1 and 2). Nested qPCR was shown to be by far the most sensitive method for detecting the SYT-SSX fusion gene transcript, followed by qPCR, nested PCR, and ddPCR (Tables 1 and 2 ). This is in line with a study conducted by Amary et al., which revealed that, when employing qPCR primers in a conventional PCR assay, the SYT-SSX fusion gene can be found in approximately $50 \%$ of cases initially classified as negative for SYT-SSX, furthermore showing that qPCR shows the highest sensitivity when compared to conventional RTPCR and FISH. However, this might be based on the PCR primer design and probably also the size of the product rather than the method of detection [26]. By combining nested PCR and $\mathrm{qPCR}$, we could further increase the sensitivity of the SYT-SSX fusion gene detection by several magnitudes, which might be useful for diagnosis of synovial sarcoma, when only very small tumor samples are available, for example, after core needle biopsy.

Still, qPCR did not prove to always be superior to ddPCR in other applications. Drandi et al. found ddPCR comparable with qPCR when detecting immunoglobulin gene rearrangement and BCL2/immunoglobulin gene major breakpoint region rearrangement in multiple myeloma, mantle cell lymphoma, and follicular lymphoma [27]. Fontanelli et al. showed slightly higher sensitivity of ddPCR for the detection of the JAK2V617F mutation in Philadelphia-negative chronic myeloproliferative neoplasms compared to qPCR [28]. However, when assessing cytomegalovirus load in clinical samples, qPCR showed greater sensitivity than did ddPCR [29]. Also, in accordance with our study, Kiselinova et al. showed that a major disadvantage of ddPCR is the high number of false-positive results when comparing ddPCR and seminested qPCR for quantification of unspliced and 
TABLE 3: Disease and therapy status of patients with synovial sarcoma. $M_{0}$ : local disease, $M_{1}:$ metastatic disease. Current chemotherapy/radiotherapy/anticoagulation involves treatment within the last 6 weeks.

\begin{tabular}{|c|c|c|c|c|c|c|}
\hline $\begin{array}{l}\text { Synovial sarcoma } \\
\text { patients }\end{array}$ & $\mathrm{M}_{0}$ & $\mathrm{M}_{1}$ & Current chemotherapy & Current radiotherapy & Anticoagulation & Fusion gene type \\
\hline Patient 1 & $\mathrm{X}$ & & & $\mathrm{X}$ & & SS18-SSX1 \\
\hline Patient 2 & & $\mathrm{X}$ & $\mathrm{X}$ & & & SS18-SSX2 \\
\hline Patient 3 & & $\mathrm{X}$ & $\mathrm{X}$ & & $\mathrm{X}$ & No tumor tissue available \\
\hline Patient 4 & & $\mathrm{X}$ & & & & SS18-SSX1 \\
\hline Patient 5 & & $\mathrm{X}$ & & & & SS18-SSX1 \\
\hline Patient 6 & & $\mathrm{X}$ & & & $\mathrm{X}$ & SS18-SSX1 \\
\hline Patient 7 & & $\mathrm{X}$ & & & & SS18-SSX2 \\
\hline Patient 8 & & $\mathrm{X}$ & & & & SS18-SSX1 \\
\hline
\end{tabular}

TABLE 4: Demographic patient data (age, body mass index (BMI), and blood count (Hb: hemoglobin level, platelet count, and leukocyte count)) of synovial sarcoma patients. Data are presented as mean value \pm standard error of mean (SEM).

\begin{tabular}{lccccc}
\hline Patients & Age $($ years $)$ & BMI $\left(\mathrm{kg} / \mathrm{m}^{2}\right)$ & $\mathrm{Hb}(\mathrm{g} / \mathrm{dL})$ & Platelets $\left(\times 10^{6} / \mathrm{L}\right)$ & Leukocytes $\left(\times 10^{6} / \mathrm{L}\right)$ \\
\hline Patients with synovial sarcoma $(n=8)$ & $50.00 \pm 4.255$ & $23.08 \pm 1.146 N=8$ & $13.23 \pm 0.6187$ & $262.6 \pm 61.43$ & $7.245 \pm 1.382$ \\
Healthy controls $(n=5)$ & $51.20 \pm 4.893$ & $23.62 \pm 1.301$ & $14.98 \pm 0.5490$ & $174.0 \pm 15.53$ & $5.468 \pm 0.4835$ \\
$p$ value & 0.8599 & 0.7682 & 0.0773 & 0.2911 & 0.3488 \\
\hline
\end{tabular}

Relative SYT-SSX-2 expression in synovial sarcoma cells and microvesicles
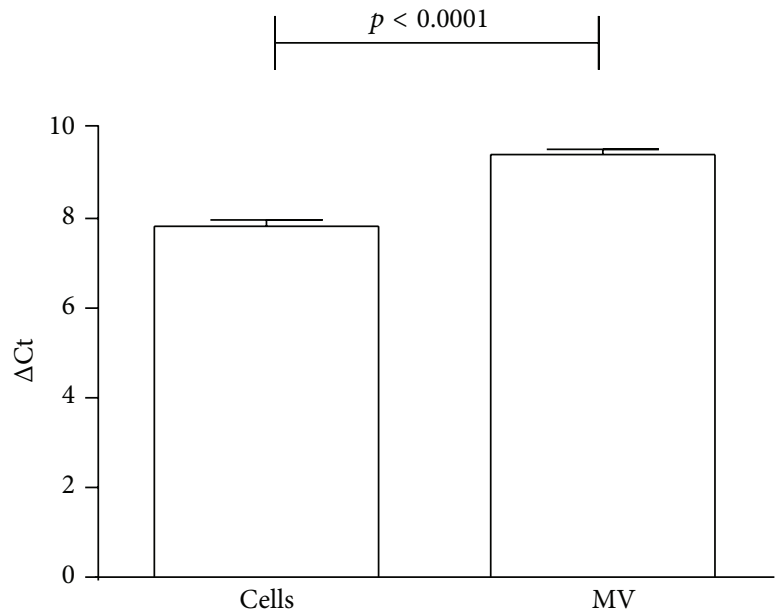

(a)
SYT-SSX2 expression

in RNase-treated and untreated microvesicles

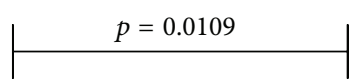

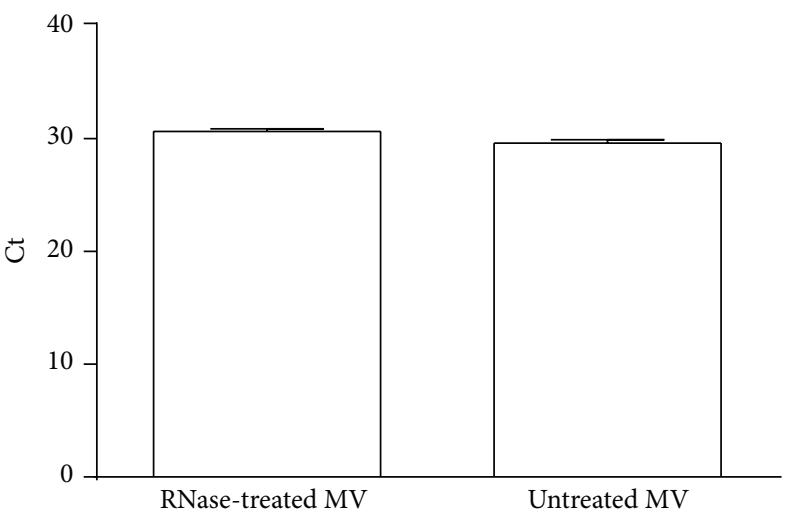

(b)

FIGURE 5: (a) Relative expression of the SYT-SSX2 fusion gene transcript in synovial sarcoma cells and microvesicles, normalized to GAPDH. (b) Expression of the SYT-SSX2 fusion gene transcript in microvesicles treated with RNase A and untreated microvesicles. MV: microvesicles.

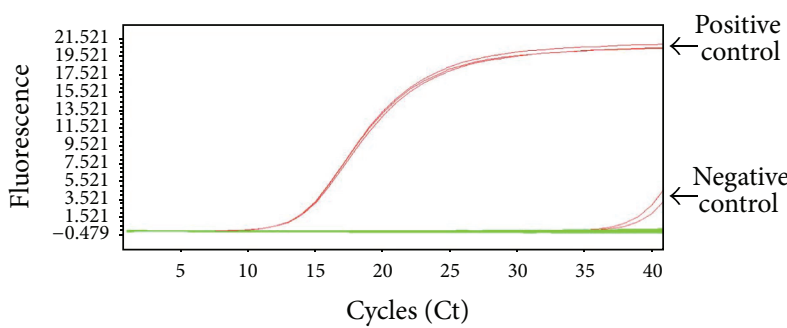

(a)

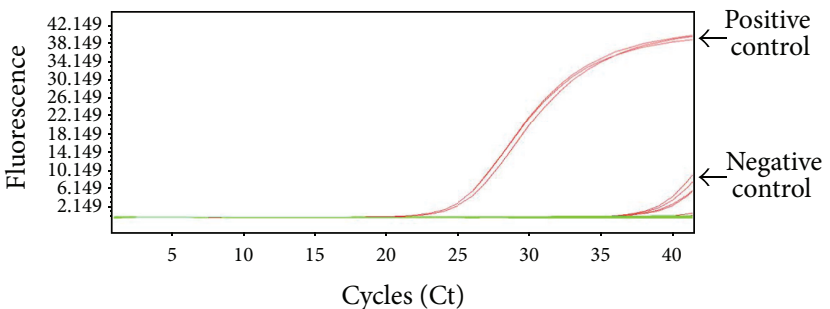

(b)

FIGURE 6: Analysis of the presence of the SYT-SSX fusion gene in whole blood, the mononuclear cell fraction, and serum microvesicles of synovial sarcoma patients by nested qPCR (a) and qPCR (b). Synovial sarcoma cells: positive control. Negative controls showed positivity at Ct-cycles $\geq 39$. Patient samples showed Ct-cycles $>39$ and were thus interpreted as negative. 


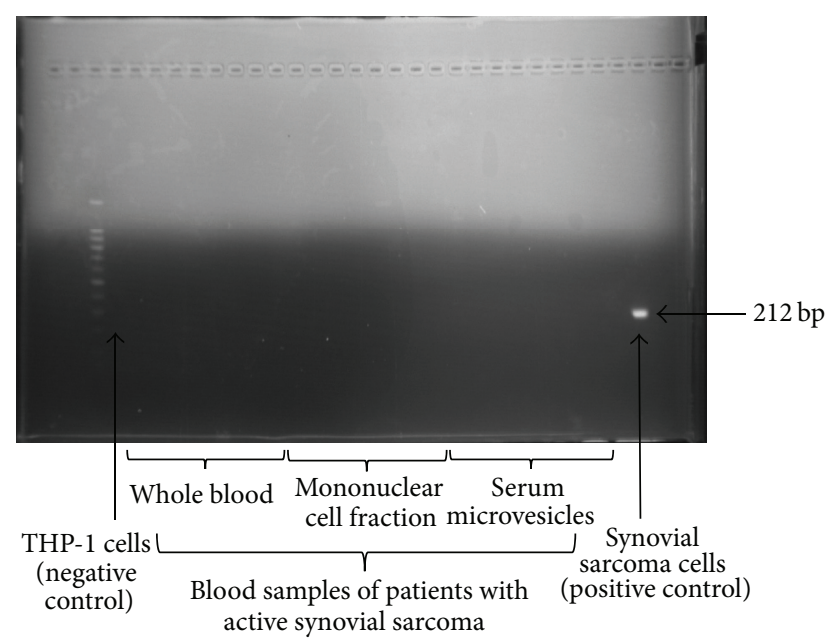

FIGURE 7: Analysis of the presence of the SYT-SSX fusion gene in whole blood, the mononuclear cell fraction, and serum microvesicles of synovial sarcoma patients by nested PCR. THP-1 cells: negative control. 1273/99 synovial sarcoma cells: positive control, showing the SYT-SSX fusion gene transcript (212 bp; the primers were designed to amplify both SYT-SSX1 and SYT-SSX2 subtypes [20]).

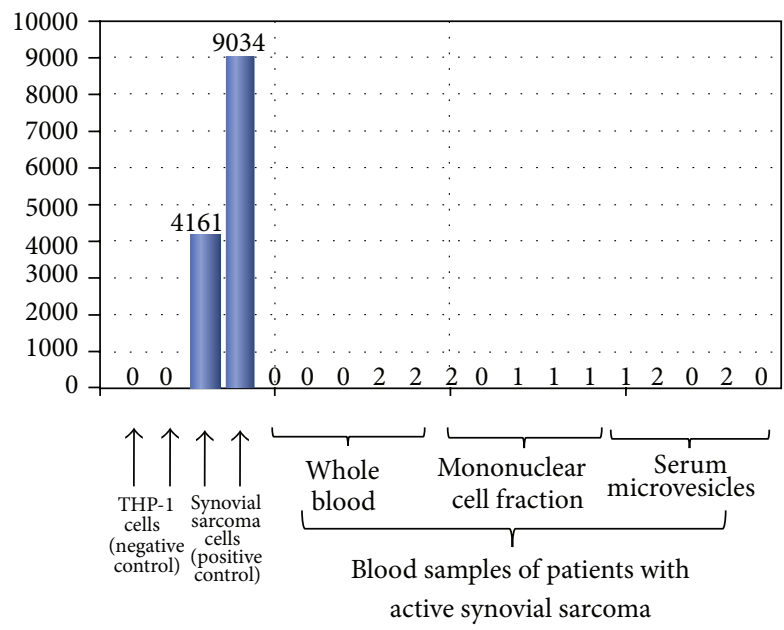

Figure 8: Analysis of the presence of the SYT-SSX fusion gene in whole blood, the mononuclear cell fraction, and serum microvesicles of synovial sarcoma patients by ddPCR.

multiply spliced HIV-1 RNA, as no-template controls were consistently negative in the seminested qPCR but yielded positive ddPCR signals [30]. Thus, it seems that the sensitivity of each method varies throughout different studies, probably being primarily dependent on the PCR primer design and size of the product.

To date, there are only few studies examining potential biomarkers of sarcoma. Recently, specific miRNA profiles were found in the peripheral blood of patients with synovial sarcoma [21] and rhabdomyosarcoma [31]. Also, research has been sparked into the field of circulating tumor cells, which have been detected in several malignancies [32, 33] and which were shown to correlate with stage of disease and presence of metastases [34] as well as with progressionfree and overall survival [35] of different neoplasms. Satelli et al. have examined cell-surface vimentin as a universal marker on circulating sarcoma cells using a monoclonal antibody, confirming the positivity of circulating tumor cells of sarcoma patients through blood spiking assays and immunofluorescence staining [36]. However, vimentin has been described in various other malignancies [37, 38], thus hardly serving as a specific biomarker.

As described in a case-report, Hashimoto et al. managed to detect tumor cells expressing the SYT-SSX fusion gene transcript in the peripheral blood of a 22-year-old pregnant woman with synovial sarcoma by nested PCR [20]. Thus, a more specific way of analyzing the presence of circulating tumor cells in sarcomas could be the detection of specific fusion gene transcripts such as the SYT-SSX fusion gene mRNA in synovial sarcoma, the EWS-ERG and EWS-FLI1 fusion transcript in Ewing sarcoma (EWS) and Primitive Neuroectodermal Tumor (PNET) [39-41], the PAX3-FKHR or PAX7-FKHR fusion transcript in alveolar rhabdomyosarcoma [42], or the ASPSCR1-TFE3 fusion transcript in alveolar soft part sarcoma (ASPS) [43]. Although Hashimoto et al. detected the SYT-SSX fusion gene product in the peripheral blood of a pregnant woman with a large synovial sarcoma of the thigh before resection of the sarcoma, the SYT-SSX fusion gene transcript could not be detected after the development of lung metastases, showing that the circulating tumor cells were reduced to an undetectable level after tumor resection [20].

Circulating tumor cells carrying a sarcoma-specific mRNA fusion gene transcript were detected only in few sarcoma patients. Schleiermacher et al. detected circulating tumor cells in the peripheral blood of $22 \%$ of patients with metastatic and $20 \%$ of patients with localized Ewing sarcoma [39]. Hoshino et al. detected the specific fusion gene transcript of ASPS, ASPSCR1-TFE3, in the peripheral blood sample of 1 ASPS patient with distant metastases [43], while Kelly et al. did not detect the PAX3-FKHR or PAX7-FKHR fusion transcript specific for alveolar rhabdomyosarcoma in any of the peripheral blood samples of alveolar rhabdomyosarcoma patients but in bone marrows of a minority of the patients [42]. This shows that, in many sarcoma patients, circulating tumor cells are reduced to an undetectable level.

The fact that Skog et al. detected the tumor-specific EGFRvIII mRNA variant specific for glioblastoma in serum microvesicles of glioblastoma patients [13] further supports our finding that circulating tumor-derived microvesicles carry tumor-specific mRNA, thus potentially serving as highly specific tumor biomarkers. Skog et al. furthermore showed that tumor-derived microvesicles deliver genetic information and proteins to surrounding cells in the tumor periphery and induce proliferation of human glioma cells.

Thus, as tumor-specific mutant mRNA can be detected in serum microvesicles from glioblastoma patients, tumorderived microvesicles may be a helpful tool in diagnosis as well as in therapeutic decisions for patients with malignant diseases.

This is especially important as these tumor-specific mRNAs can enable highly sensitive detection of tumor 
microvesicles, as we were able to detect the SYT-SSX fusion transcript by nested qPCR in total microvesicle RNA of only 6 pg (Table 2), which is less than the RNA content of a single cell.

Although we could prove that the SYT-SSX fusion gene transcript was present in synovial sarcoma microvesicles, the fusion transcript could not be detected in microvesicles isolated from the peripheral blood of synovial sarcoma patients. Thus, although tumor microvesicles seem to be ideal biomarkers for synovial sarcoma, more sensitive methods need to be developed for their detection in the peripheral circulation.

\section{Conclusions}

Synovial sarcoma cells release microvesicles which harbor the SYT-SSX fusion transcript inside their protective membrane. These vesicles might serve as a diagnostic biomarker; however, more sensitive assays are needed to detect cancerspecific microvesicles in the peripheral blood of cancer patients.

$\begin{array}{ll}\text { Abbreviations } \\ \text { ASPS: } & \text { Alveolar soft part sarcoma } \\ \text { BMI: } & \text { Body mass index } \\ \text { CISH: } & \text { Chromogenic in situ hybridization } \\ \text { dFBS: } & \text { Microvesicle-depleted fetal bovine serum } \\ \text { EWS: } & \text { Ewing sarcoma } \\ \text { FISH: } & \text { Fluorescence in situ hybridization } \\ \text { ddPCR: } & \text { Droplet Digital Polymerase Chain } \\ & \text { Reaction } \\ \text { Hb: } & \text { Hemoglobin } \\ \text { NTA: } & \text { Nanoparticle Tracking Analysis } \\ \text { PCR: } & \text { Polymerase Chain Reaction } \\ \text { PNET: } & \text { Primitive Neuroectodermal Tumor } \\ \text { qPCR: } & \text { Quantitative Polymerase Chain Reaction } \\ & \text { (real-time) } \\ \text { RT: } & \text { Room temperature } \\ \text { RT-PCR: } & \text { Reverse Transcription-Polymerase Chain } \\ & \text { Reaction } \\ \text { TEM: } & \text { Transmission electron microscopy. }\end{array}$

\section{Conflict of Interests}

The authors declare that there is no conflict of interests regarding the publication of this paper.

\section{Acknowledgments}

The authors thank Christina Engel for her technical support, Thomas Boschet, Dr. Sandra Strassburg, and Prof. Dr. Günter Finkenzeller for their invaluable advice, and Dr. Marcus Renner for his advice and the kind donation of synovial sarcoma cell line 1273/99. This work was supported by the German Research Foundation (DFG) Grants EI 866/1-2 and EI $866 / 2-1$ to PD Dr. Steffen U. Eisenhardt and a Heisenberg Fellowship by the DFG to PD Dr. Steffen U. Eisenhardt
(EI 866/4-1) as well as by the Research Commission of the University of Freiburg, Faculty of Medicine (Grant no. 3095120017) to Dr. David Braig.

\section{References}

[1] C. E. Herzog, "Overview of sarcomas in the adolescent and young adult population," Journal of Pediatric Hematology/Oncology, vol. 27, no. 4, pp. 215-218, 2005.

[2] F. C. Eilber and S. M. Dry, "Diagnosis and management of synovial sarcoma," Journal of Surgical Oncology, vol. 97, no. 4, pp. 314-320, 2008.

[3] A. J. Crew, J. Clark, C. Fisher et al., "Fusion of SYT to two genes, SSX1 and SSX2, encoding proteins with homology to the Kruppel-associated box in human synovial sarcoma," The EMBO Journal, vol. 14, no. 10, pp. 2333-2340, 1995.

[4] J. Clark, P. J. Rocques, A. J. Crew et al., "Identification of novel genes, SYT and SSX, involved in the $\mathrm{t}(\mathrm{X} ; 18)(\mathrm{p} 11.2 ; \mathrm{q} 11.2)$ translocation found in human synovial sarcoma," Nature Genetics, vol. 7, no. 4, pp. 502-508, 1994.

[5] B. Skytting, G. Nilsson, B. Brodin et al., "A novel fusion gene, SYT-SSX4, in synovial sarcoma," Journal of the National Cancer Institute, vol. 91, no. 11, pp. 974-975, 1999.

[6] C. Kadoch and G. R. Crabtree, "Reversible disruption of $\mathrm{mSWI} / \mathrm{SNF}$ (BAF) complexes by the SS18-SSX oncogenic fusion in synovial sarcoma," Cell, vol. 153, no. 1, pp. 71-85, 2013.

[7] T. O. Nielsen, N. M. Poulin, and M. Ladanyi, "Synovial sarcoma: recent discoveries as a roadmap to new avenues for therapy," Cancer Discovery, vol. 5, no. 2, pp. 124-134, 2015.

[8] M. Haldar, J. D. Hancock, C. M. Coffin, S. L. Lessnick, and M. R. Capecchi, "A conditional mouse model of synovial sarcoma: insights into a myogenic origin," Cancer Cell, vol. 11, no. 4, pp. 375-388, 2007.

[9] M. Ladanyi and J. A. Bridge, "Contribution of molecular genetic data to the classification of sarcomas," Human Pathology, vol. 31, no. 5, pp. 532-538, 2000.

[10] A. Kawai, J. Woodruff, J. H. Healey, M. F. Brennan, C. R. Antonescu, and M. Ladanyi, "SYT-SSX gene fusion as a determinant of morphology and prognosis in synovial sarcoma," The New England Journal of Medicine, vol. 338, no. 3, pp. 153-160, 1998.

[11] T. Kubo, S. Shimose, J. Fujimori, T. Furuta, and M. Ochi, "Prognostic value of SS18-SSX fusion type in synovial sarcoma; systematic review and meta-analysis," SpringerPlus, vol. 4, article 375, 2015.

[12] T. Ren, Q. Lu, W. Guo et al., "The clinical implication of SS18SSX fusion gene in synovial sarcoma," British Journal of Cancer, vol. 109, no. 8, pp. 2279-2285, 2013.

[13] J. Skog, T. Würdinger, S. van Rijn et al., "Glioblastoma microvesicles transport RNA and proteins that promote tumour growth and provide diagnostic biomarkers," Nature Cell Biology, vol. 10, no. 12, pp. 1470-1476, 2008.

[14] Y. Xie, M. Törnkvist, Y. Aalto et al., "Gene expression profile by blocking the SYT-SSX fusion gene in synovial sarcoma cells. Identification of XRCC4 as a putative SYT-SSX target gene," Oncogene, vol. 22, no. 48, pp. 7628-7631, 2003.

[15] E. Eitan, S. Zhang, K. W. Witwer, and M. P. Mattson, "Extracellular vesicle-depleted fetal bovine and human sera have reduced capacity to support cell growth," Journal of Extracellular Vesicles, vol. 4, Article ID 26373, 2015. 
[16] H. Valadi, K. Ekström, A. Bossios, M. Sjöstrand, J. J. Lee, and J. O. Lötvall, "Exosome-mediated transfer of mRNAs and microRNAs is a novel mechanism of genetic exchange between cells," Nature Cell Biology, vol. 9, no. 6, pp. 654-659, 2007.

[17] S. Hellwig, A. Masuch, S. Nestel, N. Katzmarski, M. MeyerLuehmann, and K. Biber, "Forebrain microglia from wild-type but not adult $5 \times$ FAD mice prevent amyloid- $\beta$ plaque formation in organotypic hippocampal slice cultures," Scientific Reports, vol. 5, Article ID 14624, 2015.

[18] D. Ferreira Barreto-Vieira and O. M. Barth, "Negative and positive staining in transmission electron microscopy for virus diagnosis," in Microbiology in Agriculture and Human Health, M. M. Shah, Ed., InTech, 2015.

[19] A. Keller, P. Leidinger, A. Bauer et al., "Toward the blood-borne miRNome of human diseases," Nature Methods, vol. 8, no. 10, pp. 841-843, 2011.

[20] N. Hashimoto, A. Myoui, N. Araki et al., "Detection of SYT-SSX fusion gene in peripheral blood from a patient with synovial sarcoma," The American Journal of Surgical Pathology, vol. 25, no. 3, pp. 406-410, 2001.

[21] A. Fricke, P. V. Ullrich, J. Heinz et al., "Identification of a blood-borne miRNA signature of synovial sarcoma," Molecular Cancer, vol. 14, article 151, 2015.

[22] M. Hisaoka, A. Matsuyama, Y. Nagao et al., "Identification of altered MicroRNA expression patterns in synovial sarcoma," Genes Chromosomes and Cancer, vol. 50, no. 3, pp. 137-145, 2011.

[23] M. Baj-Krzyworzeka, R. Szatanek, K. Węglarczyk et al., "Tumour-derived microvesicles carry several surface determinants and mRNA of tumour cells and transfer some of these determinants to monocytes," Cancer Immunology, Immunotherapy, vol. 55, no. 7, pp. 808-818, 2006.

[24] G. Andreola, L. Rivoltini, C. Castelli et al., "Induction of lymphocyte apoptosis by tumor cell secretion of FasL-bearing microvesicles," Journal of Experimental Medicine, vol. 195, no. 10, pp. 1303-1316, 2002.

[25] D. Barz, M. Goppelt, M. Szamel, V. Schirrmacher, and K. Resch, "Characterization of cellular and extracellular plasma membrane vesicles from a non-metastasizing lymphoma (Eb) and its metastasizing variant (ESb)," Biochimica et Biophysica Acta (BBA)-Biomembranes, vol. 814, no. 1, pp. 77-84, 1985.

[26] M. F. C. Amary, F. Berisha, F. D. C. Bernardi et al., "Detection of SS18-SSX fusion transcripts in formalin-fixed paraffinembedded neoplasms: analysis of conventional RT-PCR, qRTPCR and dual color FISH as diagnostic tools for synovial sarcoma," Modern Pathology, vol. 20, no. 4, pp. 482-496, 2007.

[27] D. Drandi, L. Kubiczkova-Besse, S. Ferrero et al., "Minimal residual disease detection by droplet digital pcr in multiple myeloma, mantle cell lymphoma, and follicular lymphoma: a comparison with real-time PCR," The Journal of Molecular Diagnostics, vol. 17, no. 6, pp. 652-660, 2015.

[28] G. Fontanelli, C. Baratè, E. Ciabatti et al., "Real-time PCR and droplet digital PCR: two techniques for detection of the JAK2(V617F) mutation in Philadelphia-negative chronic myeloproliferative neoplasms," International Journal of Laboratory Hematology, vol. 37, no. 6, pp. 766-773, 2015.

[29] R. T. Hayden, Z. Gu, J. Ingersoll et al., "Comparison of droplet digital PCR to real-time PCR for quantitative detection of cytomegalovirus," Journal of Clinical Microbiology, vol. 51, no. 2, pp. 540-546, 2013.

[30] M. Kiselinova, A. O. Pasternak, W. De Spiegelaere, D. Vogelaers, B. Berkhout, and L. Vandekerckhove, "Comparison of droplet digital PCR and seminested real-time PCR for quantification of cell-associated HIV-1 RNA," PLoS ONE, vol. 9, no. 1, Article ID e85999, 2014.

[31] M. Miyachi, K. Tsuchiya, H. Yoshida et al., "Circulating musclespecific microRNA, miR-206, as a potential diagnostic marker for rhabdomyosarcoma," Biochemical and Biophysical Research Communications, vol. 400, no. 1, pp. 89-93, 2010.

[32] A. M. Sieuwerts, J. Kraan, J. Bolt et al., "Anti-epithelial cell adhesion molecule antibodies and the detection of circulating normal-like breast tumor cells," Journal of the National Cancer Institute, vol. 101, no. 1, pp. 61-66, 2009.

[33] W. J. Allard, J. Matera, M. C. Miller et al., "Tumor cells circulate in the peripheral blood of all major carcinomas but not in healthy subjects or patients with nonmalignant diseases," Clinical Cancer Research, vol. 10, no. 20, pp. 6897-6904, 2004.

[34] J.-M. Hou, A. Greystoke, L. Lancashire et al., "Evaluation of circulating tumor cells and serological cell death biomarkers in small cell lung cancer patients undergoing chemotherapy," The American Journal of Pathology, vol. 175, no. 2, pp. 808-816, 2009.

[35] D. F. Hayes, M. Cristofanilli, G. T. Budd et al., "Circulating tumor cells at each follow-up time point during therapy of metastatic breast cancer patients predict progression-free and overall survival," Clinical Cancer Research, vol. 12, no. 14, part 1, pp. 4218-4224, 2006.

[36] A. Satelli, A. Mitra, J. J. Cutrera et al., "Universal marker and detection tool for human sarcoma circulating tumor cells," Cancer Research, vol. 74, no. 6, pp. 1645-1650, 2014.

[37] Y.-H. Kitamura, A. Shirahata, M. Sakata et al., "Frequent methylation of Vimentin in well-differentiated gastric carcinoma," Anticancer Research, vol. 29, no. 6, pp. 2227-2229, 2009.

[38] M. Li, B. Zhang, X. Wang et al., "A novel function for vimentin: the potential biomarker for predicting melanoma hematogenous metastasis," Journal of Experimental and Clinical Cancer Research, vol. 29, article 109, 2010.

[39] G. Schleiermacher, M. Peter, O. Oberlin et al., "Increased risk of systemic relapses associated with bone marrow micrometastasis and circulating tumor cells in localized ewing tumor," Journal of Clinical Oncology, vol. 21, no. 1, pp. 85-91, 2003.

[40] D. C. West, H. E. Grier, M. M. Swallow, G. D. Demetri, L. Granowetter, and J. Sklar, "Detection of circulating tumor cells in patients with Ewing's sarcoma and peripheral primitive neuroectodermal tumor," Journal of Clinical Oncology, vol. 15, no. 2, pp. 583-588, 1997.

[41] E. de Alava, M. D. Lozano, A. Patiño, L. Sierrasesúmaga, and F. J. Pardo-Mindán, "Ewing family tumors: potential prognostic value of reverse-transcriptase polymerase chain reaction detection of minimal residual disease in peripheral blood samples," Diagnostic Molecular Pathology, vol. 7, no. 3, pp. 152-157, 1998.

[42] K. M. Kelly, R. B. Womer, and F. G. Barr, "Minimal disease detection in patients with alveolar rhabdomyosarcoma using a reverse transcriptase-polymerase chain reaction method," Cancer, vol. 78, no. 6, pp. 1320-1327, 1996.

[43] M. Hoshino, A. Ogose, H. Kawashima et al., "Molecular analyses of cell origin and detection of circulating tumor cells in the peripheral blood in alveolar soft part sarcoma," Cancer Genetics and Cytogenetics, vol. 190, no. 2, pp. 75-80, 2009. 

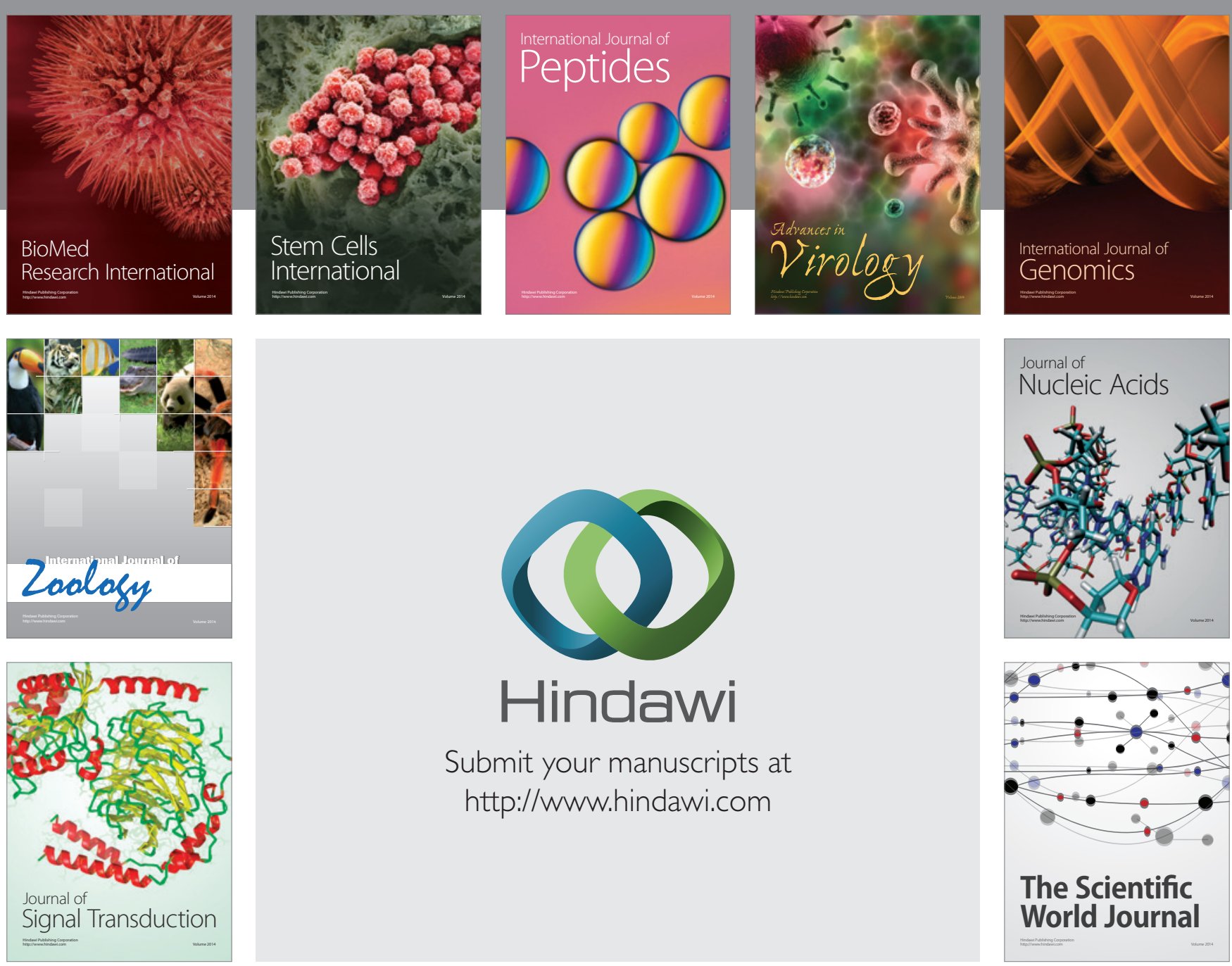

Submit your manuscripts at

http://www.hindawi.com
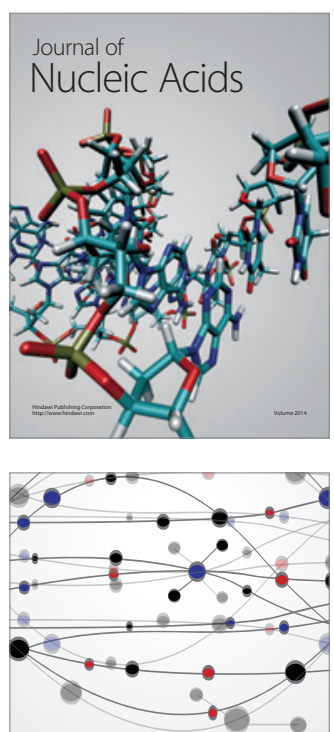

The Scientific World Journal
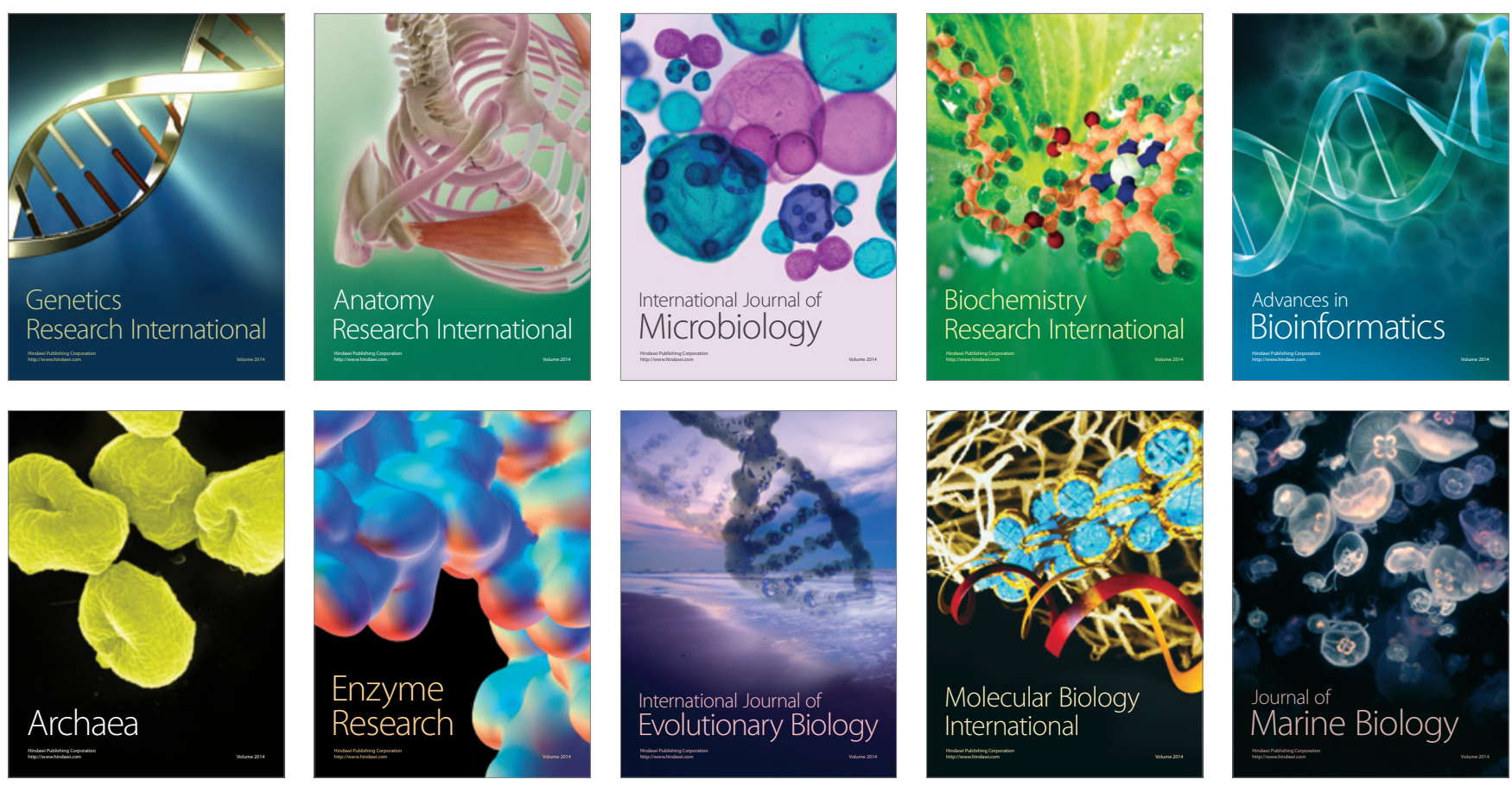